Eur. J. Clin. Chem. Clin. Biochem.

Vol. 30,1992 , pp. $333-338$

(C) 1992 Walter de Gruyter \& Co. Berlin $\cdot$ New York

\title{
Distribution of Proline-Specific Aminopeptidases in Human Tissues and Body Fluids
}

\author{
By G. Vanhoof ${ }^{1}, I$. De Meester ${ }^{1}, M$. van Sande ${ }^{1}, S$. Scharpé ${ }^{1}$ and A. Yaron ${ }^{2}$ \\ ${ }^{1}$ Department of Medical Biochemistry, Faculty of Medicine, University of Antwerp, Wilrijk, Belgium \\ ${ }^{2}$ Department of Membrane Research and Biophysics, Weizmann Institute of Science, Rehovot, Israel
}

(Received August 16, 1991/April 10, 1992)

Summary: The proline-specific peptidases, aminopeptidase P (EC 3.4.11.9) and dipeptidyl peptidase IV (EC 3.4.14.5), were measured in human tissue homogenates and physiological fluids. All tissues examined contained measurable aminopeptidase $P$ and dipeptidyl peptidase IV activities. High specific activities for both enzymes under study were found in benign prostatic hypertrophy. Normal prostate and prostatic adenocarcinoma had a much lower activity. This difference, however, is not reflected in the serum values of the patients. The most striking finding is the extremely high activity of dipeptidyl peptidase IV in prostatosomes, prostate-derived organelles, which occur freely in human seminal plasma, and which are important for enhancement of sperm forward motility.

\section{Introduction}

Peptide bonds containing a proline residue are resistant to a wide variety of peptidases and proteases. The proline-specific enzymes, aminopeptidase $P$ (EC 3.4.11.9) ${ }^{1}$ ) and dipeptidyl peptidase IV (EC 3.4.14.5) $)^{1}$ ), require a proline at the penultimate position of the amino-terminus in the substrate sequence. Degradation from the $\mathrm{N}$-terminus of naturally occurring peptides containing a proline at this particular location depends largely on these peptidases. Dipeptidyl peptidase IV is an exopeptidase that removes $\mathrm{N}$ terminal dipeptides from polypeptides with unsubstituted $\mathrm{N}$-termini. The penultimate residue must be proline, hydroxyproline, or alanine, the greatest hydrolysis rate occurring with proline provided that the third residue is neither proline nor hydroxyproline. Aminopeptidase $\mathrm{P}$ is a metallo-aminopeptidase that

\footnotetext{
1) Enzymes

Aminopeptidase M (EC 3.4.11.2)

Aminopeptidase P (EC 3.4.11.9)

Dipeptidyl peptidase II (EC 3.4.14.2)

Dipeptidyl peptidase IV (EC 3.4.14.5)

Leucyl aminopeptidase (EC 3.4.11.1)

Prolyl aminopeptidase (EC 3.4.11.5)
}

catalyses specifically the removal of any unsubstituted $\mathrm{N}$-terminal amino acid, including proline, that is adjacent to a penultimate proline residue. Due to their specificity towards proline, it has been suggested that dipeptidyl peptidase IV and aminopeptidase $\mathrm{P}$ are important in the digestion of otherwise resistant dietary protein fragments, thereby complementing the pancreatic peptidases $(1,2)$, and in the maturation and degradation of peptide hormones, neuropeptides, and tachykinins $(3-6)$. There is evidence for the participation of aminopeptidase $P$ and dipeptidyl peptidase IV in the activation and proliferation of Tlymphocytes $(7,8)$. Recently, the T-cell surface dipeptidyl peptidase IV has been identified as the cluster differentiation factor CD26 (9).

Cleavage of the proline-containing $\alpha$-chain of fibrin by dipeptidyl peptidase IV results in an inhibition of fibrin polymerization (10). The high proline content in collagen has led to the suggestion of a function for aminopeptidase $\mathrm{P}$ and dipeptidyl peptidase IV in collagen metabolism $(11,12)$. More recently it has been shown that dipeptidyl peptidase IV is directly involved in cellular adhesion to extracellular matrix proteins by serving as a functional collagen receptor (13). 
Moreover, the determination of dipeptidyl peptidase IV activity in serum and cerebrospinal fluid has taken on diagnostic significance $(14-16)$. Although the distribution of aminopeptidase $\mathrm{P}$ and dipeptidyl peptidase IV in mammals has been extensively explored $(17-20)$ and although important species differences have been observed $(19,20)$, the distribution of aminopeptidase $\mathrm{P}$ and dipeptidyl peptidase IV in different human organs has yet to be systematically studied. Here, we report the results of a study of the specific activity of aminopeptidase $P$ and dipeptidyl peptidase IV in human tissue extracts and body fluids.

\section{Materials and Methods}

\section{Body fluids}

Sera for reference values were obtained from blood donors, sperm from healthy donors, and prostatic fluid from vasectomised individuals.

For determination of the enzyme activity in serum from patients with benign prostatic hypertrophy and with prostatic cancer, blood samples were taken from patients admitted to the urology service of the University Hospital of Antwerp for symptoms of obstruction of the pars prostatica urethrae. Blood samples were centrifuged at $900 \mathrm{~g}$ for $10 \mathrm{~min}$. Serum was aspirated and stored at $-20^{\circ} \mathrm{C}$. After diagnosis of the disease, 41 serum samples of patients with benign prostatic hypertrophy and 30 samples of patients with prostatic cancer were retained for the study. $\mathrm{Pa}$ tients treated by transurethral resection of the prostate were omitted from the study to avoid falsly elevated levels of enzyme activity. By means of transrectal echography of the prostate, CAT-scan of the abdomen and pelvis minor, liver-milt-scan, RX of the thorax, echography of liver and abdomen, and bone scan, the patients with prostatic carcinoma were classified according to the American urological system in classes A1 to D2.

\section{Tissues}

The tissues were obtained by open surgery. Except when specifically noted, only parts of tissue not involved in the disease process were used. Prostatectomy was performed in patients with prostatic carcinoma and benign prostatic hypertrophy. Normal prostate tissue was acquired from patients with bladder cancer. All tissues were washed with cold saline and stored as soon as possible in liquid nitrogen, brought to the laboratory, and kept frozen at $-80^{\circ} \mathrm{C}$. Tissue homogenates were made by grinding the tissues in a Potter-Elvejhem glass homogenizer fitted with a Teflon pestle, either with one drop of Nonidet P40 (LKB, Bromma, Sweden) per $200 \mathrm{mg}$ tissue, or by the method of Lazo \& Quinn (22), using a $30 \mathrm{mmol} / 1$ solution of octyl- $\beta$ $D$-glucopyranoside (Calbiochem-Behring, La Jolla, LA, USA). After centrifugation at $50000 \mathrm{~g}$ for 30 minutes at $4{ }^{\circ} \mathrm{C}$, the supernatant was stored at $-80^{\circ} \mathrm{C}$ until determination of aminopeptidase $\mathrm{P}$ and dipeptidyl peptidase IV activity and protein concentration.

\section{Differential centrifugation of seminal plasma}

Seminal plasma was centrifuged at $900 \mathrm{~g}$ for $10 \mathrm{~min}$ in a MSE HI-spin 21 centrifuge (MSE Scientific Instruments, Sussex, UK), resulting in a pellet containing the spermatozoa and a supernatant. The supernatant was centrifuged at $105000 \mathrm{~g}$ for $120 \mathrm{~min}$ in a Beckman ultracentrifuge model L350 (Beckman Instruments, München, Germany), to precipitate the prosta- tosomes. The supernatant contains the seminal fluid. The spermatozoan and prostatosome pellets were separately resuspended in $20 \mathrm{mmol} / \mathrm{l}$ Tris, $\mathrm{pH} 7.4,1 \%$ Triton X-100, and centrifuged at $40000 \mathrm{~g}$ for $20 \mathrm{~min}$.

\section{Protein measurement}

Protein concentrations were determined by the bicinchoninic acid-detection reagent (Pierce Chemical Company, Rockford, IL, USA). Bovine serum albumin was used as the standard.

\section{Enzyme assays}

Aminopeptidase $P$ activity was measured using the intramolecularly quenched fluorogenic substrate Lys(2,4 dinitrophenyl)Pro-Pro-NH- $\mathrm{CH}_{2}-\mathrm{CH}_{2}-\mathrm{NH}$-2-aminobenzoyl $\cdot 2 \mathrm{HCl}$ (17). The samples are incubated at $40^{\circ} \mathrm{C}$ with $0.5 \mathrm{mmol} / \mathrm{l}$ substrate in 0.2 $\mathrm{mol} / \mathrm{l}$ Tris- $\mathrm{HCl}, \mathrm{pH} 8.0,10 \mathrm{mmol} / \mathrm{l}$ trisodium citrate and 2.6 $\mathrm{mmol} / 1 \mathrm{MnSO}_{4}$. The reaction is stopped by the addition of 0.2 $\mathrm{mol} / \mathrm{l}$ Tris- $\mathrm{HCl}, \mathrm{pH} 8.0,50 \mathrm{mmol} / \mathrm{l}$ EDTA, $1 \mathrm{mmol} / 1$ dithiothreitol. Fluorescence measurements were performed at excitation wavelength $320 \mathrm{~nm}$ and emission wavelength $410 \mathrm{~nm}$. Dipeptidyl peptidase IV activity was determined by a fluorometric and a colorimetric method. The manual fluorometric method has been described elsewhere (23). Briefly, the enzyme is incubated at $37^{\circ} \mathrm{C}$ with $1.4 \mathrm{mmol} / \mathrm{l}$ Gly-Pro-4-methoxy-2naphthylamide in $50 \mathrm{mmol} / 1$ Tris- $\mathrm{HCl}, \mathrm{pH}$ 8.3. The reaction is stopped by the addition of $0.1 \mathrm{~mol} / \mathrm{l}$ citrate buffer $\mathrm{pH} 4.0$, after which the fluorescence of the formed 4-methoxy-2-naphthylamine is measured at excitation wavelength $340 \mathrm{~nm}$ and at an emission wavelength of $425 \mathrm{~nm}$. When necessary, tissue extracts were diluted before measurement of the enzyme activities to keep product formation within the limits of method linearity. Possible interference in the dipeptidyl peptidase IV assay by successive cleavage by aminopeptidases (all metalloproteases) of the substrate Gly-Pro-4-methoxy- $\beta$-napthylamide was controlled by measurement of the residual activity after inhibition of dipeptidyl peptidase IV by addition of diisopropyl fluorophosphate to the tissue extracts to a final concentration of 1.5 $\mathrm{mmol} / \mathrm{l}$. To check for the presence of substances in the tissue extracts exerting a quenching effect in the fluorometric assay (24), the colorimetric method described by Nagatsu et al. (25), which uses the chromogenic substrate glycyl- $L$-proline- $p$-nitroanilide tosylate, was adapted for direct continuous measurement on the centrifugal analyser Cobas Bio (Roche Diagnostics, Germany). The within- and between-run precisions of the assay were both less than $2 \% \mathrm{CV}(\mathrm{n}=10)$. One unit of enzyme catalytic activity was defined as the amount of enzyme catalysing the formation of $1 \mu \mathrm{mol}$ assay product per minute under assay conditions.

\section{Results}

The specific activities of aminopeptidase $P$ and dipeptidyl peptidase IV, expressed in U/g protein are presented in figures 1 and 2.

Dipeptidyl peptidase IV activities were determined fluorometrically and colorimetrically. Both methods proved to be useful for the determination of dipeptidyl peptidase IV in tissue extracts. The specific activities determined by either method correlated well for each extract, thus excluding the possibility that the fluorescence measurements are subjects to interference by quenching substances in the tissue extracts. Dipeptidyl peptidase II (EC 3.4.14.2) $)^{1}$ ) also attacks Gly-Pro- 


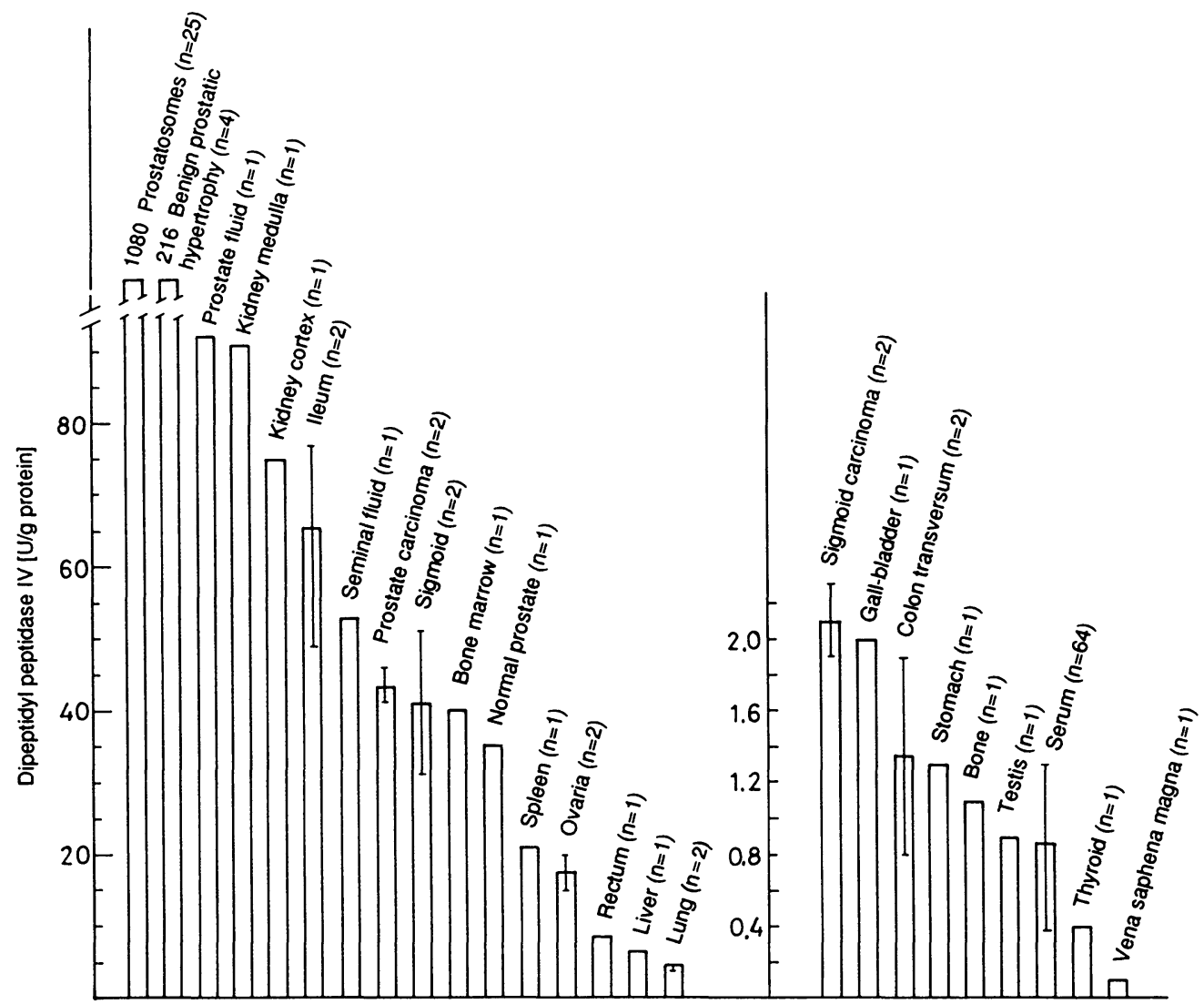

Fig. 1. Distribution of dipeptidyl peptidase IV in human tissue extracts and body fluids. The vertical bars indicate the range in specific activity obtained for the number $(n)$ of tissues examined. Note the extremely high values in prostasomes (range $295-1813 \mathrm{U} / \mathrm{g}$ protein) and in prostates from patients suffering from benign prostatic hypertrophy (range $98-315 \mathrm{U} / \mathrm{g}$ protein).

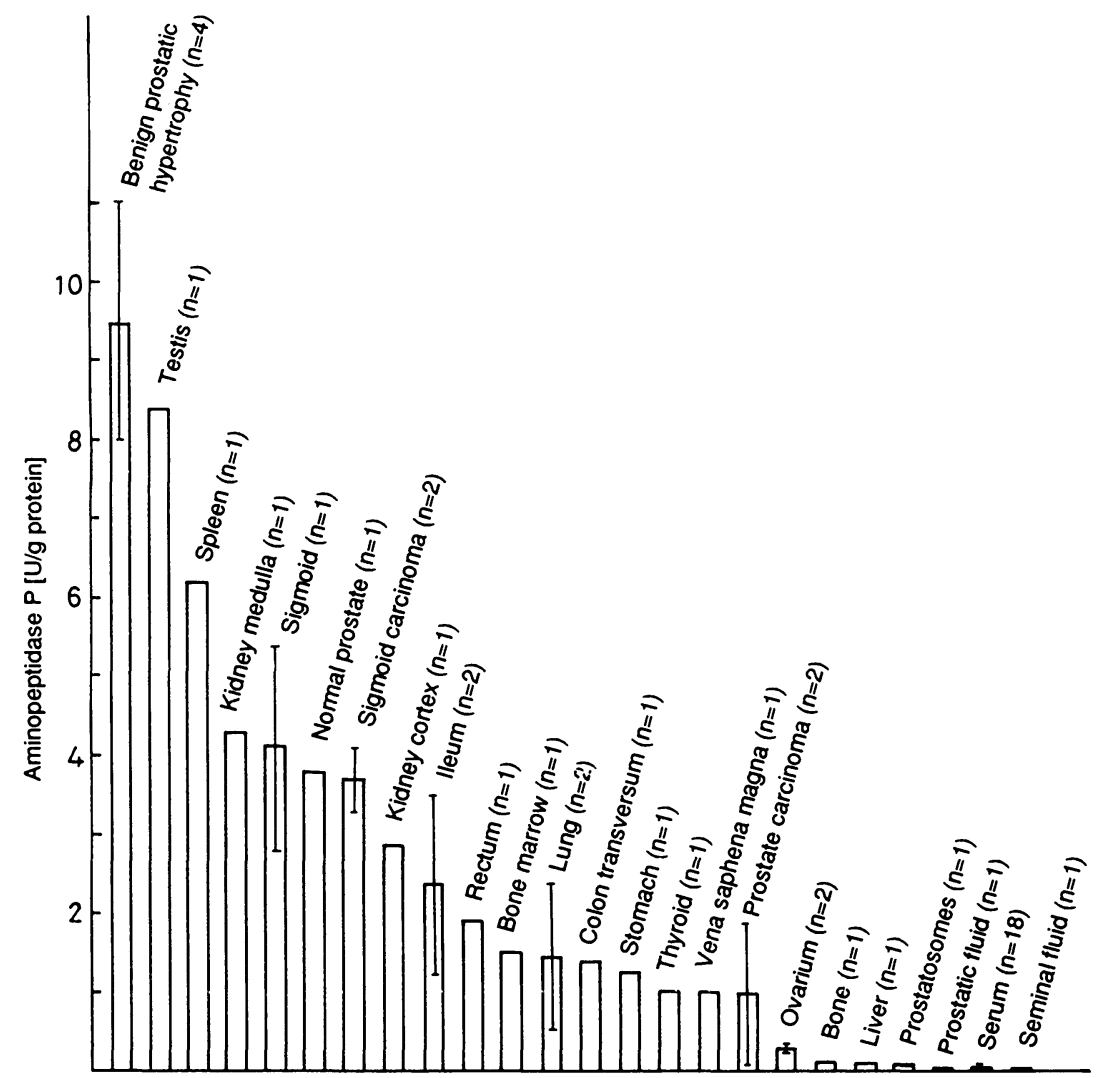

Fig. 2. Distribution of aminopeptidase $P$ in human tissue extracts and body fluids. The vertical bars indicate the range in specific activity obtained for the number ( $\mathrm{n}$ ) of tissues examined. 
arylamides with direct release of a fluorescent product (26). Interference by this peptidase, which has a $\mathrm{pH}$ optimum below $\mathrm{pH} 6$, was excluded by working at a high $\mathrm{pH}$ value $(\mathrm{pH} 8.3)$. Aminopeptidase $\mathrm{P}$ can remove the $\mathrm{N}$-terminal Gly from the substrate, resulting in Pro-arylamide. The Pro can be removed by leucylaminopeptidase (EC 3.4.11.1) $)^{2}$ ), which has recently been shown to be identical to prolyl aminopeptidase $\left.(\text { EC 3.4.11.5) })^{1}\right)(27,28)$, and aminopeptidase M (EC 3.4.11.2) $)^{1}$, resulting in the formation of the fluorescent product. As a control for the successive cleavage of the substrate by these metallopeptidases, the dipeptidyl peptidase IV activity was inhibited by 1.5 $\mathrm{mmol} / \mathrm{l}$ diisopropyl fluorophosphate and the residual activity was measured following the standard assay procedure (23). In all measured extracts, the residual activity remained below $5 \%$ except for the gall bladder $(17 \%)$, the sigmoid carcinoma $(11 \%)$, the colon transversum $(10 \%)$ and for the ovarium extract $(7 \%)$. Because of the significant differences in the specific activities of the proline-specific enzymes in tissue from benign prostatic hypertrophy and prostatic cancer, we checked to see whether this difference is reflected in the enzyme serum values of the patients. The results are listed in table 1 . No significant difference in dipeptidyl peptidase IV and aminopeptidase $\mathrm{P}$ serum values between patients suffering from benign prostatic hypertrophy or prostatic carcinoma and normal individuals were detected. Only the serum aminopeptidase $\mathrm{P}$ activity is significantly correlated with the

Tab. 1. Aminopeptidase $P$ and dipeptidyl peptidase IV activities in serum of healthy individuals and of patients with benign prostatic hypertrophy and with prostatic carcinoma.

\begin{tabular}{lll}
\hline & Aminopeptidase P & $\begin{array}{l}\text { Dipeptidyl } \\
\text { peptidase IV }\end{array}$ \\
\hline $\begin{array}{l}\text { Healthy } \\
\text { individuals }\end{array}$ & \\
mean* & 3.7 & 58.3 \\
n & 41 & 123 \\
SD* & 2.4 & 12.9 \\
range* & $0.3-11.8$ & $22-85$ \\
Benign prostatic & & \\
hypertrophy & & \\
mean & 3.6 & 50.2 \\
n & 42 & 41 \\
SD & 2.3 & 12.5 \\
range & $0.0-10.6$ & $24-78$ \\
Prostatic & & \\
carcinoma & & 52.7 \\
mean & 5.0 & 30 \\
n & 29 & 31.1 \\
SD & 4.3 & $19-182$ \\
range & $0.7-18.2$ & \\
\hline
\end{tabular}

* mean, range, and $\mathrm{SD}$ are expressed in $\mathrm{U} / 1$ tumour stage ( $p=0.03$, Spearman rank correlation test) in untreated patients. However, when the aminopeptidase $P$ serum value of a mixed group of treated and untreated patients with prostatic carcinoma was compared with the development of the tumour, no correlation could be demonstrated ( $p=0.71$, Spearman rank correlation rest).

\section{Discussion}

Our studies on extracted tissues show that all organs examined contain dipeptidyl peptidase IV as well as aminopeptidase $\mathrm{P}$ activity, but the distribution of the enzymes differs significantly. For both enzymes, by far the highest specific activity was found in prostatic tissue extracts from patients suffering from benign prostatic hypertrophy. The striking difference in specific activities of both peptidases between patients suffering from benign prostatic hypertrophy and prostatic cancer is not reflected in the serum values of the patients. Although the serum aminopeptidase $P$ activity of untreated patients with prostatic cancer is significantly correlated with the tumour stage, this serum value is in our opinion of no clinical use, since no correlation was found in a mixed group of treated and untreated patients. The most striking finding is the extremely high specific activity of dipeptidyl peptidase IV in prostatosomes, prostate-derived organelles that occur freely in human seminal fluid. Human testicular tissue contains very low dipeptidyl peptidase IV activity. These results suggest that dipeptidyl peptidase IV from seminal plasma is at least partly synthesised in human prostate and secreted into the prostatic duct, thus contributing to the activity in seminal plasma. The physiological function of dipeptidyl peptidase IV in human seminal plasma is still unclear. Substance $P$, which regulates the activation of acetylcholine, can be cleaved by dipeptidyl peptidase IV. The activity of dipeptidyl peptidase IV can thus indirectly influence the role of acetylcholine in the regulation of sperm motility (29). Because of the high specific activity of dipeptidyl peptidase IV in human prostatosomes, the involvement of prostatosomes in sperm forward motility (30) may be at least partly due to its dipeptidyl peptidase IV activity. As could be predicted from previous studies $(31,32)$, high aminopeptidase $\mathrm{P}$ and dipeptidyl peptidase IV activities were found in human kidney and small intestine. Much attention has already been paid to, and evidence given for, the role of both proline-specific enzymes in peptide metabolism and transport in the brush border of the kidney and the small intestine $(33-35)$. In contrast to the distribution of aminopeptidase $\mathrm{P}$ in rat organs, where the specific activity is 
by far the highest in the lung and ovary, we found relatively low activities for aminopeptidase $\mathrm{P}$ as well as for dipeptidyl peptidase IV in the human lung, relative to the other organs. The activity of aminopeptidase $\mathrm{P}$ and dipeptidyl peptidase IV in human lung is important for evaluating the significance for human physiology of the studies by Baker et al. (36). These authors showed that the combined action of aminopeptidase $\mathrm{P}$ and dipeptidyl peptidase IV produces the major metabolite formed during inactivation of circulating bradykinin in perfused rat lung. Human aminopeptidase $\mathrm{P}$, however, is present in blood cells in a higher specific activity than in human lung $(7,37,38)$. Care must therefore be taken not to apply findings for rat bradykinin metabolism directly to the human physiology, since other organs and especially blood cells may contribute more to bradykinin metabolism in humans than in rats. However, since human aminopeptidase $\mathrm{P}$ has a high affinity for bradykinin and since none of the angiotensins are substrates for aminopeptidase $\mathrm{P}$, the development of specific inhibitors for aminopeptidase $P$ may be useful for the highly selective control of bradykinin metabolism.

\section{References}

1. Sahara, N., Fukasawa, K., Harada, M. \& Suzuki, K. (1989) Subcellular localization of dipeptidyl peptidase IV in rat kidney and small intestine. Acta Histochem. Cytochem. 22, 479-486.

2. Lasch, J., Koelsch, R., Ladhoff, A. M. \& Hartrodt, B. (1986) Is the proline-specific aminopeptidase $P$ of the intestinal brush border an integral membrane enzyme? Biomed. Biochim. Acta 45, 833-843.

3. Püschel, G., Mentlein, R. \& Heymann, E. (1982) Isolation and characterization of dipeptidyl peptidase IV from human placenta. Eur. J. Biochem. 126, 359-365.

4. Orawski, A. T., Susz, J. P. \& Simmons, W. H. (1987) Aminopeptidase $\mathrm{P}$ from bovine lung: solubilisation, properties and potential role in bradykinin degradation. Mol. Cell. Biochem. 75, 123-132.

5. Fleminger, G. \& Yaron, A. (1983) Sequential hydrolysis of proline containing peptides with immobilized aminopeptidases. Biochim. Biophys. Acta 743, 437-446.

6. Nausch, I., Mentlein, R. \& Heymann, E. (1990) The degradation of bioactive peptides and proteins by dipeptidyl peptidase IV from human placenta. Biol. Chem. HoppeSeyler 371, 1113-1118.

7. Hendriks, D., De Meester, I., Umiel, T., Vanhoof, G., van Sande, M., Scharpé, S. \& Yaron, A. (1991) Aminopeptidase $\mathrm{P}$ and dipeptidyl peptidase IV activity in human leucocytes and stimulated lymphocytes. Clin. Chim. Acta 196, 87-96.

8. Schön, E., Sigbert, J., Kiessig, S. T., Demuth, H. U., Neubert, K., Barth, A., Von Baehr, R. \& Ansorge, S. (1987) The role of dipeptidyl peptidase IV in human T lymphocyte activation. Inhibitors and antibodies against dipeptidyl peptidase IV suppress lymphocyte proliferation and immunoglobulin synthesis in vitro. Eur. J. Immunol. 17, $1821-$ 1826.
It is clear that the distribution of both enzymes varies considerably between species $(19,21)$. Therefore, the present study adds to the present knowledge of the possible functions of aminopeptidase $\mathrm{P}$ and dipeptidyl peptidase IV in human tissues. Since all activities were measured in total tissue extracts, one has to be cautious in interpreting attempts to define a general physiological role for a given enzyme. More detailed localization of the enzyme activities in the different tissues are required to be able to correlate the observations with the availability of possible biologically active substrates. The extremely high activity of dipeptidyl peptidase IV in human prostatosomes, however, is a very interesting observation, which deserves further investigation as part of the search for mechanisms controlling male fertility.

\section{Acknowledgement}

We would like to thank Prof. Dr. K. Van Camp and Dr. E. Bosmans for their scientific support. I. De Meester is a research assistant sponsored by the Belgian National Fund for Scientific Research. A. Yaron is an incumbent of the Morris Belkin Professorial Chair in Cancer Research of the Department of Membrane Research and Biophysics, Weizmann Institute of Science, Rehovot, Israel.

9. Barton, R. W., Prendergast, J. \& Kennedy, C. A. (1990) Binding of the $\mathrm{T}$ cell activation monoclonal antibody $\mathrm{Ta} 1$ to dipeptidyl peptidase IV. J. Leukocyte Biol. 48, $291-$ 296.

10. Mentlein, R. \& Heymann, E. (1982) Dipeptidyl peptidase IV inhibits the polymerization of fibrin monomers. Arch. Biochem. Biophys. 217, 748-750.

11. Dehm, P. \& Nordwig, A. (1970) The cleavage of prolyl peptides by kidney peptidases. Partial purification of a " $\mathrm{X}$ Prolyl-Aminopeptidase" from swine kidney microsomes. Eur. J. Biochem. 17, 364-371.

12. Mc Conald, J. K. \& Schwabe, C. (1977) Intracellular exopeptidases. In: Proteinases in Mammalian Cells and Tissues (Barrett, A. J., ed.) p. 311 Elsevier/North Holland Biomedical Press, New York.

13. Dang, N. H., Torimoto, Y., Schlossman, S. F. \& Morimoto, C. (1990) Human CD4 helper T-cell activation: functional involvement of two distinct collagen receptors, $1 \mathrm{~F} 7$ and VLA integrin family. J. Exp. Med. 172, 649-652.

14. Hagihara, M., Ohhashi, M. \& Nagatsu, T. (1987) Activities of dipeptidyl peptidase II and dipeptidyl peptidase IV in mice with lupus erythematosus-like syndrome and in patients with rheumatoid arthritis. Clin. Chem. 33, 14631465.

15. Fujita, K., Hirano, M., Ochiai, J., Funabashi, M., Nagatsu, I., Nagatsu, T. \& Sakakibara, S. (1978) Serum glycylproline p-nitroanilidase activity in rheumatoid arthritis and systemic lupus erythematosus. Clin. Chim. Acta 88, 15-20.

16. Kallenbach, W., Küllertz, G., Fischer, G. \& Barth, A. (1986) Die Validität der postprolinspaltenden Dipeptidyl-aminopeptidase-Aktivitäten im Liquor cerebrospinalis für die neurologisch-psychiatrische Diagnostik. Psychiat. Neurol. Med. Psychol., Leipzig 38, 456-463. 
17. Holtzman, E. J., Pullay, G., Rosenthal, T. \& Yaron, A. (1987) Aminopeptidase P activity in rat organs and human serum. Anal. Biochem. 162, 476-484.

18. Tauc, M., Chatelet, F., Verroust, P., Vandewalle, A., Poujeol, P. \& Ronco, P. (1988) Characterization of monoclonal antibodies specific for rabbit renal brush border hydrolases. Application to immunohistological localization. J. Hist. Cyt. 36, 523-532.

19. Hartel, S., Gossrau, R., Hanski, C. \& Reutter, W. (1988) Dipeptidyl peptidase (DPP) IV in rat organs. Histochemistry $88,151-161$.

20. Hooper, N. M. \& Turner, A. J. (1988) Ectoenzymes of the kidney microvillar membrane. Aminopeptidase $P$ is anchored by a glycosyl-phosphatidylinositol moiety. FEBS Letters 229, 340-344.

21. Chen, X. L., Orphanes, S. E., Ryan, J. W., Chung, A. Y. K. \& Catravas, J. D. (1984) Species variation in aminopeptidase $\mathrm{P}$ activity in vivo and in vitro. FASEB J. 3, A1026.

22. Lazo, J. T. \& Quinn, D. E. (1980) Solubilization of pulmonary angiotensin-converting enzyme with $1-O-n$-octyl- $\beta$ $D$-glucopyranoside. Anal. Biochem. 102, 68-71.

23. Scharpé, S., De Meester, I., Vanhoof, G., Hendriks, D., van Sande, M., Van Camp, K. \& Yaron, A. (1988) Assay of dipeptidyl peptidase IV in serum by fluorometry of 4methoxy-2-naphthylamine. Clin. Chem. 34, 2299-2301.

24. Kenny, A. J., Booth, A., George, S., Ingram, J., Kershaw, J., Wood, E. J. \& Young, A. R. (1976) Dipeptidyl peptidase IV, a kidney brush border serine peptidase. Biochem. J. $157,169-182$.

25. Nagatsu, T., Hino, M., Fuyamada, H., Hayakawa, T., Sakakibara, S., Nakagawa, Y. \& Takemoto, T. (1976) New chromogenic substrates for X-prolyl dipeptidyl-aminopeptidase. Anal. Biochem. 74, 466-476.

26. Küllertz, G., Barth, A. \& Fischer, G. (1986) Die Bestimmung der Dipeptidyl-Peptidase IV in biologischen Materialien. J. Clin. Chem. Clin. Biochem. 24, 551- 558.

27. Matsushima, M., Takahashi, T., Ichinose, M., Miki, K., Kurokawa, K. \& Takahashi, K. (1991) Structural and immunological evidence for the identity of prolylaminopeptidase with leucyl aminopeptidase. Biochem. Biophys. Res. Commun. 178, 1459-1464.

28. Turzynski, A. \& Mentlein, R. (1990) Prolyl aminopeptidase from rat brain and kidney. Action on peptides and identification as leucyl aminopeptidase. Eur. J. Biochem. 190, $509-515$.
29. Dwivedi, C. \& Long, N. J. (1989) Effect of cholinergic agents on human spermatozoa motility. Biochem. Med. Metab. Biol. 42, 66-70.

30. Stegmayer, B. \& Ronquist, G. (1982) Stimulation of sperm progressive motility by organelles in human seminal plasma. Scand. J. Urol. 16, 85-90.

31. Hama, T., Okada, M., Koijima, K., Kato, T., Matsuyama, M. \& Nagatsu, T. (1982) Purification of human dipeptidylaminopeptidase IV from human kidney cortex. Mol. Cell. Biochem. 43 35-42.

32. Wolf, G. B., Scherberich, J. E., Fischer, P. \& Schoeppe, W. (1989) Isolation and characterization of dipeptidyl aminopeptidase IV from human kidney cortex. Clin. Chim. Acta $179,61-72$.

33. Blau, N., Niederwieser, A. \& Shmerling, D. H. (1988) Peptiduria presumably caused by aminopeptidase $\mathrm{P}$ deficiency. A new inborn error of metabolism. J. Inher. Metab. Dis. $11,240-242$.

34. Morita, A., Chung, Y. C., Freeman, H. J., Erickson, R. H., Sleisenger, M. H. \& Kim, Y. S. (1983) Intestinal assimilation of a proline-containing tetrapeptide. J. Clin. Invest. $72,610-616$

35. Tiruppathi, C., Muyamoto, Y., Ganapathy, V., Roesel, R., Whitford, G. \& Leibach, F. (1990) Hydrolysis and transport of proline-containing peptides in renal brush-border membrane vesicles from dipeptidyl peptidase IV positive and dipeptidyl peptidase IV negative rat strains. J. Biol. Chem. 265, 1476-1483.

36. Baker, C. R. F. Jr., Little, A. D., Little, G. H., Canizaro, P. C. \& Behal, F. J. (1991) Kinin metabolism in the perfused ventilated lung. I: Bradykinin metabolism in a system modeling the normal, uninjured lung. Circulatory Shock 33, $37-47$.

37. Scharpé, S., Vanhoof, G., De Meester, I., Hendriks, D., van Sande, M., Muylle, L. \& Yaron, A. (1990) Exopeptidases in human platelets: an indication for proteolytic modulation of biologically active peptides. Clin. Chim. Acta $195,125-132$.

38. Sidorowicz, W., Canizaro, P. C. \& Behal, F. J. (1984) Kinin cleavage by human erythrocytes. Am. J. Hematol. 17, 383391.

Prof. Dr. S. Scharpé

University of Antwerp, UIA

Universiteitsplein 1

B-2610 Wilrijk 